\title{
Hematological Findings in Children with Brucellosis
}

\author{
Bruselloz Tanılı Çocuklarda Hematolojik Bulgular
}

\author{
Tuğçe Tural Kara'(iD), Ahmet Kan²(ID) \\ ${ }^{1}$ Clinic of Pediatric Infectious Diseases, Hatay State Hospital, Hatay, Turkey \\ ${ }^{2}$ Clinic of Pediatric Allergy and Immunology, Hatay State Hospital, Hatay, Turkey
}

Cite this article as: Tural Kara T, Kan A. Hematological findings in children with brucellosis. J Pediatr Inf 2020;14(3):e111-e116.

Abstract

Objective: Brucellosis is a zoonotic infection that causes multiple organ involvement. It is an important public health problem especially in areas where animal husbandry is widespread. The disease causes clinical and laboratory findings depending on the region of the body. The aim of this study was to evaluate the clinical and hematological findings of patients with brucellosis.

Material and Methods: Pediatric patients admitted to our hospital between October 2017 and October 2019 and diagnosed with brucellosis were analyzed retrospectively. Patients receiving the recommended treatment for a total of six weeks and applying to the hospital due to control one month after the end of treatment were included in the study.

Results: A total of 70 pediatric patients were included into the study. Hematologic findings were $145.7 \%(n=32)$ anemia, $12.9 \%(n=9)$ leukopenia, $11.4 \%(n=8)$ leukocytosis, $2.9 \%(n=2)$ thrombocytopenia and $1.4 \%(n=1)$ pancytopenia. Low level in at least one series (cytopenia) was seen in $52.9 \%$ $(n=37)$ of patients. Bacteremia, alanine aminotransferase and aspartate aminotransferase elevation ( $>40 \mathrm{U} / \mathrm{L}$ ) were significantly higher in the group with cytopenia compared to the group without cytopenia $(p=0.02, p=$ $0.002, p=0.003$, respectively). Brucella spp. was isolated in 10 (14.3\%) blood cultures. Anemia, thrombocytopenia, at least one cytopenia and splenomegaly were found to be higher in the bacteriemic group than the non-bacteriemic group ( $p=0.038, p=0.03, p=0.017, p=0.004$, respectively). After brucellosis treatment, hemoglobin levels were significantly increased ( $p=$ $0.001)$, whereas $C$-reactive protein $(p=0.003)$, sedimentation $(p=0.001)$, alanine aminotransferase $(p<0.001)$ and aspartate aminotransferase $(p<0.001)$ were significantly decreased. At the first month after treatment, $37.5 \%$ of the patients with anemia, $88.9 \%$ of the patients with leukopenia and all patients with thrombocytopenia had normal complete blood counts.

Conclusion: Brucellosis may cause hematological complications in children. It may be possible to achieve improvement in hematological findings with appropriate time and dose of brucellosis treatment. Therefore, brucellosis should be kept in mind of the differential diagnosis of anemia, leukopenia and thrombocytopenia.

Keywords: Anemia, brucellosis, child, leukopenia, thrombocytopenia
Öz

Giriş: Bruselloz çoklu organ tutulumuna neden olan zoonotik bir enfeksiyondur. Özellikle hayvancılığın yaygın olduğu yerlerde önemli bir halk sağlığı sorunudur. Hastalık vücutta tuttuğu bölgeye göre klinik ve laboratuvar bulgulara neden olmaktadır. Çalışmamızda bruselloz tanısı ile izlediğimiz hastaların klinik ve hematolojik bulgularının değerlendirilmesi amaçlanmıştır.

Gereç ve Yöntemler: Ekim 2017-Ekim 2019 tarihleri arasında hastanemize başvurmuş ve bruselloz tanısı almış çocuk hastalar geriye dönük olarak incelenmiştir. Toplam altı hafta önerilen tedaviyi almış, tedavi bitiminden bir ay sonra kontrol için hastaneye başvurmuş hastalar çalışmaya alınmıştır.

Bulgular: Toplam 70 çocuk hasta çalışmaya dahil edildi. Hematolojik açıdan \%45.7 ( $n=32)$ anemi, \%12.9 $(n=9)$ lökopeni, \%11.4 $(n=8)$ lökositoz, \%2.9 $(n=2)$ trombositopeni ve \%1.4 $(n=1)$ pansitopeni saptandı. En az bir seride düşüklük (sitopeni) \%52.9 $(n=37)$ hastada görüldü. Sitopeni olan grupta, sitopeni olmayan gruba kıyasla bakteriyemi, alanin aminotransferaz ve aspartat aminotransferaz yüksekliği (> $40 \mathrm{U} / \mathrm{L}$ ) anlamIı yüksek bulundu (sırasıyla $p=0.02, p=0.02, p=0.003$ ). Kan kültüründe 10 (\%14.3) hastada Brucella spp. izole edildi. Bakteremik grupta anemi, trombositopeni, en az bir sitopeni ve splenomegali bakteriyemik olmayan gruba göre yüksek saptandı (sırasıyla $p=0.038, p=0.03, p=0.017, p=$ 0.004). Tedavi sonrası hemoglobin düzeylerinde anlamlı yükselme olurken $(p=0.001), C$-reaktif protein $(p=0.003)$, sedimentasyon $(p=0.001)$, alanin aminotransferaz $(p<0.001)$ ve aspartat aminotransferaz $(p<0.001)$ değerlerinde de anlamlı düşme oldu. Tedaviden sonraki ilk ayda anemili hastaların \%37.5'inde ve lökopenili hastaların \%88.9'unda ve trombositopenili hastaların hepsinde tam kan sayımı normal olarak bulundu.

Sonuç: Çocuklarda bruselloz hematolojik komplikasyonlara neden olabilmektedir. Uygun sürede ve dozda bruselloz tedavisi ile hematolojik bulgularda düzelme elde etmek mümkün olabilir. Bu nedenle anemi, lökopeni, trombositopeni ayırıcı tanısında bruselloz akılda tutulmalıdır.

Anahtar Kelimeler: Anemi, bruselloz, çocuk, lökopeni, trombositopeni

Correspondence Address/Yazışma Adresi

Tuğçe Tural Kara

Hatay Devlet Hastanesi,

Çocuk Enfeksiyon Hastalıkları Kliniği,

Hatay-Türkiye

E-mail: tugcetural@hotmail.com 


\section{Introduction}

Brucellosis is a zoonotic infection transmitted to humans by direct or indirect contact with infected animals, inhalation of infected droplets, or consumption of raw milk and dairy products (1). It is estimated that there are 500.000 new brucellosis cases annually in the world. In our country, it is an important healthcare problem in regions where animal husbandry is commonly-practiced, including Southeast Anatolia, East Anatolia, and Central Anatolia (2). Diagnosis is made by serologic tests accompanied by characteristic clinical findings and/or bacteria isolation from cultures taken from sterile regions like the blood or bone marrow.

Brucellosis is a multisystemic diseases with expansive clinical and laboratory findings that might cause diagnostic difficulties. It can involve nearly any organ and result in the emergence of clinical findings specific to the area and organ involved. Complaints such as fever, malaise, weakness, and joint pain are generally seen in patients $(3,4)$. Due to the orientation of Brucella spp. specifically towards the reticulo-endothelia system like the bone barrow and spleen, disease involvement in these organs are encountered (5). It can cause abnormalities in laboratory findings, as well. Despite leading to mostly leucopenia and mild anemia hematologically, it has been reported to cause pancytopenia and thrombocytopenia due to the granulomatous variations it induces in the bone marrow and rarely hemophagocytosis and hypersplenism (5-7).

There are limited data on the hematologic involvement of brucellosis in pediatric patients. Our region is a brucellosis endemic region where animal husbandry is the livelihood of local people. Our study aimed at evaluating the hematologic findings of brucellosis and the impact of these findings on treatment.

\section{Materials and Methods}

Pediatric patients, aged 0-18 years, admitted to the Pediatric Infectious Diseases Clinic of our hospital between October 2017 and October 2019 and diagnosed with brucellosis were analyzed retrospectively. The study included patients having received the recommended 6-week treatment (doxycycline + gentamycin or doxycycline+ rifampicin or co-trimoxazole + rifampicin) and followed-up one month after the end of the treatment for laboratory examinations. Patients with underlying diseases and those receiving blood, blood products or any form of drugs were excluded from the study.

As a result of clinical findings, patients in whom serum agglutination tests were performed and found as $\geq 1 / 160$ titer and/or those in whom Brucella spp. was isolated in blood culture were accepted as brucellosis patients. For blood cultures, automatic blood culture device BACTEC 9120 (Becton Dickinson) and blood culture bottles were used.

According to the duration of the symptoms, patients with symptoms lasting less than eight weeks were assessed as acute brucellosis, those with symptoms lasting between 8-52 weeks were assessed as subacute brucellosis, and patients with symptoms lasting more than one year were assessed as chronic brucellosis (8). From the patient files, we compiled data on demographic and clinical characteristics such as age, sex, complaints on presentation, starting time of the complaints, risk factors in terms of contamination, place of residence, consumption of raw milk and dairy products, family history of brucellosis, and family occupation regarding animal husbandry, findings of physical examination, complete blood count, white blood cell, neutrophil, lymphocyte, monocyte and thrombocyte counts, C-reactive protein (CRP), and sedimentation rate, alanine aminotransferase (ALT), aspartate aminotransferase (AST) values, Brucella agglutination test, growth in blood culture, and if relapse occurred.

Anemia is defined as a hemoglobin concentration under 2 standard deviations (SD) or average for a healthy population at the same age and sex. The lower limit for hemoglobin levels as per age is as follows: $11 \mathrm{~g} / \mathrm{dL}$ for the first 3 years of age, $11.7 \mathrm{~g} /$ $\mathrm{dL}$ for the ages between 4-6 years, $12 \mathrm{~g} / \mathrm{dL}$ for the ages between 7-10 years, $12.3 \mathrm{~g} / \mathrm{dL}$ for girls between the ages $11-14$ years and $12.6 \mathrm{~g} / \mathrm{dL}$ for boys, $11.5 \mathrm{~g} / \mathrm{dL}$ for girls between the ages $15-18$ years and $13.7 \mathrm{~g} / \mathrm{dL}$ for boys, and these levels are considered as anemia (9-11). The lower limit of leucocyte count for leucopenia definition as per age is accepted as follows: $5000 / \mathrm{mm}^{3}$ for the ages between 1 month and 1 year, $6000 / \mathrm{mm}^{3}$ for the ages between 1 and 10 years, $4500 / \mathrm{mm}^{3}$ for the ages of 10 and older (12). Leukocytosis is defined as the leucocyte count over 10.000 in $\mathrm{mm}^{3}$. Thrombocytopenia is defined as the thrombocyte count below 150.000 in $\mathrm{mm}^{3}$ and thrombocytosis is defined as

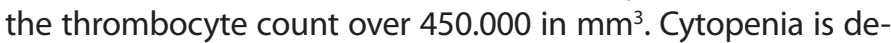
fined as lowness in one of the levels of hemoglobin, leucocyte or thrombocyte, bicytopenia is lowness in two series, and pancytopenia is lowness in all three series.

SPSS 22.0 program was used for the statistical analysis of the data obtained. In order to evaluate the relation between the potential risk factor of brucellosis and cytopenia prevalence (pancytopenia, bicytopenia and leucopenia), univariate analyses were performed using Chi-square test, Student's t-test and Mann-Whitney $\mathrm{U}$ test. In the comparison of laboratory findings of the patients on admission and one month after the end of treatment, Paired sample $t$ test was used. Statistical significance was set at $p<0.05$.

\section{Results}

A total of 70 patients were included into the study. $51.4 \%$ of them were males. Mean age was $120.76 \pm 60.07$ months. $45.7 \%$ of the patients were living in the rural area. History of consuming raw milk and dairy products was established in $82.9 \%$ of the patients. Families of $31.4 \%$ of the patients were engaged in animal husbandry, and previous brucellosis history was present in half of their families. According to the duration of the symptoms, $50 \%$ received acute brucellosis, $44.3 \%$ received subacute brucellosis, and $5.7 \%$ received chronic brucellosis diagnosis. The patients were most commonly presented with joint pain (74.3\%), fever (72.9\%), malaise (71.4\%), loss of appetite (67.1\%), 
and abdominal pain (47.1\%). Physical examination determined fever in $7.1 \%$ of the patients $(n=5)$, arthritis in $10 \%(n=7)$, hepatomegaly in $5.7 \%(n=4)$, splenomegaly in $5.7 \%(n=4)$, and lymphadenopathy in $11.4 \%(n=8)$. Brucella agglutination test in all patients was 1/160 and higher, an in 52 patients (74.3\%), Brucella agglutination test was determined as $\geq 1 / 640$. Table 1 summarizes the demographic and clinical findings of the patients.

Considering hematological findings, anemia was determined in 32 (45.7\%) patients, leucopenia in 9 (12.9\%), leukocytosis in 8 (11.4\%), thrombocytopenia in 2 (2.9\%), and pancytopenia in 1 (1.4\%) patient. It was seen in 32 of the 37 (52.95) patients in whom lowness in at least one series (cytopenia) occurred that there was lowness in only one series, and bicytopenia and pancytopenia development were confirmed in four patients and one patient, respectively. When patients who had and had not developed cytopenia were compared, a difference was not detected among the demographic and clinical characteristics between the groups; however, blood culture positivity $(p=0.02)$, ALT value of $>40 \mathrm{U} / \mathrm{L}(\mathrm{p}=0.02)$, and AST value of $>40$ $U / L(p=0.003)$ in the cytopenia group were found statistically significantly high. Group comparisons as per cytopenia presence are given in Table 2.

Table 1. Demographic and clinical findings of the children diagnosed with brucellosis

\begin{tabular}{|c|c|c|c|}
\hline & n (\%) & Symptoms & n (\%) \\
\hline Number of patients & 70 & Joint pain & $52(74.3)$ \\
\hline Male & $36(51.4)$ & Fever & $51(72.9)$ \\
\hline Age (mean $\pm S S)$, month & $120.76 \pm 60.07$ & Malaise & $50(71.4)$ \\
\hline$\geq 5$ age & $57(81.4)$ & Loss of appetite & $47(67.1)$ \\
\hline 5-1 age & $12(17.1)$ & Abdominal pain & $33(47.1)$ \\
\hline$<1$ age & $1(1.4)$ & Muscle pain & $32(45.7)$ \\
\hline Living in the rural area & $32(45.7)$ & Sweating & $30(42.9)$ \\
\hline Consumption of raw milk and dairy products & $58(82.9)$ & Weight loss & $26(37.1)$ \\
\hline Husbandry & $22(31.4)$ & Lumbar pain & $25(35.7)$ \\
\hline Brucellosis history in the family & $35(50)$ & Swelling in joints & $15(21.4)$ \\
\hline Duration of symptoms (mean \pm SS), day & $91.89 \pm 137.47$ & & \\
\hline Acute brucellosis & $35(50)$ & & \\
\hline Subacute brucellosis & $31(44.3)$ & & \\
\hline Chronic brucellosis & $4(5.7)$ & & \\
\hline
\end{tabular}

Table 2. Comparison of demographic, clinical, and laboratory findings of the groups as per the presence of cytopenia

\begin{tabular}{|c|c|c|c|}
\hline & Presence of cytopenia $(n=37)(\%)$ & Absence of cytopenia $(n=33)(\%)$ & $\mathrm{p}$ \\
\hline Sex (male) & $16(43.2)$ & $20(60.6)$ & 0.16 \\
\hline Living in the rural area & $20(54.1)$ & $12(36.4)$ & 0.15 \\
\hline Consumption of raw milk and dairy products & $32(86.5)$ & $26(79.8)$ & 0.53 \\
\hline Husbandry & $13(35.1)$ & $9(27.3)$ & 0.61 \\
\hline Brucellosis history in the family & $18(48.6)$ & $17(51.5)$ & 1 \\
\hline Acute brucellosis & $20(54.1)$ & $15(45.5)$ & \multirow{3}{*}{0.63} \\
\hline Subacute brucellosis & $15(40.5)$ & $16(48.5)$ & \\
\hline Chronic brucellosis & $2(5.4)$ & $2(6)$ & \\
\hline Fever & $28(75.7)$ & $23(69.7)$ & 0.60 \\
\hline Growth in blood culture & $9(24.3)$ & $1(3)$ & 0.02 \\
\hline $\mathrm{ALT}>40 \mathrm{U} / \mathrm{L}$ & $12(32.4)$ & $3(9.1)$ & 0.02 \\
\hline AST > $40 \mathrm{U} / \mathrm{L}$ & $15(40.5)$ & $3(9.1)$ & 0.003 \\
\hline Aggluination $\geq 1: 640$ & $29(78.4)$ & $23(69.7)$ & 0.43 \\
\hline Relapse & $1(2.7)$ & $4(12.1)$ & 0.18 \\
\hline
\end{tabular}


Table 3. Group comparisons according to blood culture positivity

\begin{tabular}{|l|c|c|c|}
\hline & Presence of bacteremia $(\mathbf{n}=\mathbf{1 0})(\%)$ & Absence of bacteremia $(\mathbf{n}=\mathbf{4 8})(\%)$ & $\mathbf{p}$ \\
\hline Splenomegaly & $3(30)$ & $0(0)$ & $\mathbf{0 . 0 0 4}$ \\
\hline Hepatomegaly & $1(10)$ & $3(6.3)$ & 0.54 \\
\hline Anemia & $8(80)$ & $20(41.7)$ & $\mathbf{0 . 0 3 8}$ \\
\hline Leucopenia & $3(30)$ & $5(10.4)$ & 0.13 \\
\hline Thrombocytopenia & $2(20)$ & $0(0)$ & $\mathbf{0 . 0 3}$ \\
\hline At least one cytopenia & $9(90)$ & $11(22.9)$ & $\mathbf{0 . 0 1 7}$ \\
\hline ALT $(>40$ U/L) & $3(30)$ & $13(27.1)$ & 0.69 \\
\hline AST $(>40 \mathrm{U} / \mathrm{L})$ & $4(40)$ & & 0.46 \\
\hline ALT: Alanin aminotransferaz, AST: Aspartat aminotransferaz. & & \\
\hline
\end{tabular}

Table 4. Comparison of laboratory findings of the patients ate the time of presentation and one month after the end of treatment

\begin{tabular}{|l|c|c|c|}
\hline & $\begin{array}{c}\text { Presentation } \\
(\mathbf{n = 7 0 )}(\text { mean } \pm \text { SS) }\end{array}$ & $\begin{array}{c}\text { After treatment } \\
(\mathbf{n = 7 0 )} \text { (mean } \pm \text { SS) }\end{array}$ & $\mathbf{p}$ \\
\hline Hemoglobin $(\mathrm{g} / \mathrm{dL})$ & $12.3 \pm 1.5$ & $72.7 \pm 1.2$ & $\mathbf{0 . 0 0 1}$ \\
\hline White blood cell $\left(/ \mathrm{mm}^{3}\right)$ & $7435.6 \pm 2331.3$ & $3242.9 \pm 1400.2$ & 0.27 \\
\hline Lymphocyte $\left(/ \mathrm{mm}^{3}\right)$ & $3326.0 \pm 1564.5$ & $3038.6 \pm 1502.1$ & 0.56 \\
\hline Neutrophil $\left(/ \mathrm{mm}^{3}\right)$ & $3471.7 \pm 1825.9$ & $507.1 \pm 178.0$ & 0.12 \\
\hline Monocyte $\left(/ \mathrm{mm}^{3}\right)$ & $639.1 \pm 917.2$ & $316571.4 \pm 74203.9$ & 0.24 \\
\hline Thrombocyte count $\left(/ \mathrm{mm}^{3}\right)$ & $300762.9 \pm 88827.6$ & $2.9 \pm 6.6$ & 0.05 \\
\hline C-reactive protein $(\mathrm{mg} / \mathrm{L})$ & $8.3 \pm 13.9$ & $9.2 \pm 8.8$ & $\mathbf{0 . 0 0 3}$ \\
\hline Sedimentation $(\mathrm{mm} / \mathrm{saat})$ & $22.0 \pm 30.9$ & $13.8 \pm 8.1$ & $\mathbf{0 . 0 0 1}$ \\
\hline ALT $(\mathrm{U} / \mathrm{L})$ & $33.4 \pm 38.8$ & $22.1 \pm 8.4$ & $<\mathbf{0 . 0 0 1}$ \\
\hline AST $(\mathrm{U} / \mathrm{L})$ & $39.0 \pm 35.3$ & & $<\mathbf{0 0 1}$ \\
\hline ALT: Alanin aminotransferaz, AST: Aspartat aminotransferaz. & & \\
\hline
\end{tabular}

Blood culture was not taken in $12(17.1 \%)$ patients. There was no bacteria isolated from the blood cultures of 48 (68.6\%) patients and Brucella spp. was isolated in 10 (14.3\%) patients. When 58 patients, whose blood cultures were taken, were compared according to the frequency of anemia, leucopenia, and thrombocytopenia, the prevalence of anemia, thrombocytopenia, and ate least one cytopenia in the bacteriemic group was found statistically significantly higher compared to the non-bacteriemic group (respectively, $p=0.038 ; p=0.03 ; p=$ 0.017). No difference was confirmed in the prevalence of leucopenia between patients in whom growth was detected and not detected in blood cultures. Splenomegaly was also determined more in the bacteriemic group $(p=0.004)$. No difference was found between the groups in terms of elevation in AST and ALT levels (AST > $40 \mathrm{U} / \mathrm{L}$ and ALT $>40 \mathrm{U} / \mathrm{L}$ ). Table 3 summarizes group comparisons as per culture positivity.

There were 70 patients presenting one month after the termination of treatment. These patients had not received any blood, blood product or drug therapy during the 6-week brucellosis treatment. A statistically significant elevation in hemoglobin levels $(p=0.001)$ and a statistically significant decrease in CRP $(p=0.003)$, sedimentation $(p=0.001), \operatorname{ALT}(p<0.001)$, and AST $(p<0.001)$ levels were confirmed in patients after treatment. Furthermore, it was seen that hemoglobin levels of $37.5 \%$ of the patients with anemia (12/32) returned to normal ranges. It was also confirmed that white blood cell and thrombocyte counts returned to normal levels in a majority of the patients in whom leucopenia (8/9) and thrombocytopenia (2/2) were detected. Table 4 summarizes laboratory parameters examined at the time of presentation and one month after treatment.

\section{Discussion}

Brucellosis is a serious problem in regions where animal husbandry is commonly practiced. Along with the fact that data on the seroprevalence of the disease in children are limited, $20 \%-30 \%$ of all brucellosis cases in the world and specifically in endemic regions are comprised of pediatric patients (13). Approximately 15.000 new cases are confirmed in Turkey, and pediatric patients make up of $20-25 \%$ of all cases (14). We evaluated the demographic and clinical characteristics of pediatric patients diagnosed with brucellosis in our region where animal husbandry is commonly-practiced. 
Main source of infection in brucellosis is the consumption of raw milk and dairy products and contact with infected animals (1). In a study by Gül et al. examining 1110 pediatric patients diagnosed with brucellosis, $30.2 \%$ of the patients' families were engaged in animal husbandry and $73.2 \%$ produced their own cheese. It has been reported by the authors that only $35.1 \%$ of the families boiled the milk before making cheese and the remaining mildly heated the milk before use (15). $45.7 \%$ of the cases in our study were living in the rural region, and $31.4 \%$ of the patients' families were engaged in animal husbandry. Furthermore, similar to the literature, a majority (82.9\%) consumed raw milk and dairy products.

The disease is generally seen in males and school-aged children. The reason for this is the fact that boys are more in contact with animals and risky food compared to girls (16-19). Boys were found more in our study (54.1\%), and majority of the cases were children older than 5 years (82.4\%). There was only one patient younger than 12 months. This 4-month-old girl was only breastfed but the mother had a history of consuming fresh cheese.

Brucellosis is a systemic disease that may induce multi-organ involvement. Hematologically, it can cause mild anemia, leucopenia, thrombocytopenia, and rarely pancytopenia (5,2023). There are studies in the literature regarding hematological findings in children diagnosed with brucellosis $(6,7,20-22)$. However, there is no study investigating the effect of brucellosis treatment on hematological findings. This study aimed at evaluating the effect of treatment on hematological findings by comparing laboratory findings of the patients at the time of presentation and one month after the 6-week treatment.

In the literature, the most common hematological finding in children diagnosed with brucellosis has been reported as anemia, with a prevalence of $20-50 \%(6,24,25)$. In the study by Karaman et al. including 622 children diagnosed with brucellosis, anemia (28.6\%), thrombocytopenia (16\%), and leucopenia (13.9\%) have been found the most common (20). Change in iron metabolism secondary to infection, hypersplenism, bleeding, suppression in the bone marrow, and autoimmune hemolysis are held responsible for anemia (21). In the study by Justman et al. including 511 pediatric patients diagnosed with brucellosis, anemia has been confirmed lower (13.3\%) compared to the data of the literature. However, the authors have attributed the low anemia rates for having accepted the hemoglobin threshold level as $10 \mathrm{mg} / \mathrm{dL}$ so as to decrease the number of anemia cases unrelated to brucellosis. Other hematological findings of the study were leucopenia (28.3\%), thrombocytopenia (14.5\%), and pancytopenia (1.8\%) (5).

Together with not fully knowing the pathogenesis of thrombocytopenia in brucellosis, several factors including hypersplenism, bone marrow suppression due to septicemia, hemophagocytosis, and peripheral immune destruction of thrombocytes are considered as agents (26). Aypak et al. have studied 69 pediatric patients diagnosed with brucellosis and asserted that thrombocytopenia was the most commonly seen (15.9\%) hematological finding. Moreover, while it has been reported that thrombocytosis (7.3\%), leucopenia (5.8\%), anemia (4.3\%), and bicytopenia (4.3\%) were seen, pancytopenia was not observed in any patients. Thrombocyte count has been detected statistically significantly low in these patients who were bacteriemic when compared to non-bacteriemic ones. Therefore, the authors have underlined that brucellosis should be considered in the differential diagnosis of isolated thrombocytopenia (22). We are of the opinion that the high level of prevalence of splenomegaly, anemia, thrombocytopenia, and at least one cytopenia found in the bacteriemic patients of our study is related to splenomegaly secondary to infection and hypersplenism. In the literature, hematological findings are seen more in patients with blood culture positivity and acute brucellosis cases compared to subacute and chronic brucellosis cases (13). When the groups were compared regarding the presence of cytopenia in our study, it is supported that bacteremia is an important factor in the development of cytopenia. Similarly, Justman et al. have found in their study consisting 511 children diagnosed with brucellosis that older age, fever, Brucella spp. positivity in blood culture, and agglutination test of $\geq 1: 640$ are associated with cytopenia (5). However, when we compared the groups with and without cytopenia, we did not find any difference in terms of factors other than bacteremia, ALT and AST elevation.

Hypersplenism, granulomatous lesions in the bone marrow, hemophagocytosis, autoimmune process, and bone marrow suppression due to septicemia are hold responsible for the development pf pancytopenia (24). In a study evaluating 54 pediatric patients diagnosed with brucellosis, pancytopenia has been detected at a rate of $14.8 \%$. Pancytopenia was temporary in all patients and ameliorated after appropriate antibiotic treatment (27). In a study by Çitak et al. evaluating 146 pediatric patients diagnosed with brucellosis, pancytopenia has been confirmed in 9 of the patients. After the completion the brucellosis treatment, blood values of all patients, except one, were within normal ranges. Allogenic bone marrow transplantation was carried out for this patient who did not respond to treatment. The authors have reported that appropriate antimicrobial treatment ameliorates the clinical and hematological findings of brucellosis (23).

Mild and moderate elevation can be determined in liver function tests associated with liver involvement in brucellosis $(13,28)$. Moreover, elevation in CRP and sedimentation values has been reported as commonly seen laboratory abnormalities $(7,29)$. In our study, while decrease was detected in the levels of CRP, sedimentation, ALT, and AST after brucellosis treatment in our study, elevation was also confirmed in hemoglobin levels. We are of the opinion that elevation in hemoglobin levels without the use of any blood, blood products, and drugs other than those prescribed for brucellosis treatment is secondary to the regression of hypersplenism and bone marrow suppression related to the control of the infection. 
In conclusion, brucellosis may cause hematological findings in pediatric patients. Important factor in the development of cytopenia is growth in the blood culture. Moreover, hematological complications can be encountered more frequently in bacteriemic patients compared to non-bacteriemic ones. However, it is possible to obt5ain improvement in findings with brucellosis treatment administered at an appropriate duration and dosage. Therefore, brucellosis should be considered in the differential diagnosis of cytopenia.

Ethics Committe Approval: The ethical approval for this study was obtained from Hatay Mustafa Kemal University (Decision number: 03 Date: 08.08.2019).

Informed Consent: None due to the retrospective nature of the study.

Peer-review: Externally peer-reviewed.

Author Contributions: Consept - TTK; Design - TTK; Supervision TTK; Resources - TTK, AK; Data Collection and/or Processing - TTK, AK; Analysis and/or Interpretation - TTK, AK; Literature Review- TTK, AK; Writing - TTK; Critical Review -TTK, AK.

Conflict of Interest: No conflict of interest was declared by the authors.

Financial Disclosure: The authors declared that this study has received no financial support.

\section{References}

1. Logan LK, Jacobs NM, McAuley JB, Weinstein RA, Anderson EJ. A multicenter retrospective study of childhood brucellosis in Chicago, Illinois from 1986 to 2008. Int J Infect Dis 2011;15:812-7. [CrossRef]

2. Abuhandan $M$, Güzel B, Çakmak A, Çiçek A. Çocuklarda bruselloz: 82 olgunun retrospektif olarak değerlendirilmesi. J Pediatr Inf 2012;6:74-8. [CrossRef]

3. Pappas G, Akritidis N, Bosilkovski M, Tsianos E. Brucellosis. N Engl J Med 2005;352:2325-36. [CrossRef]

4. Apa H, Devrim I, Memur S, Günay I, Gülfidan G, Celegen M, et al. Factors affecting Brucella spp. blood cultures positivity in children. Vector Borne Zoonotic Dis 2013;13:176-80. [CrossRef]

5. Justman N, Fruchtman $Y$, Greenberg D, Ben-Shimol S. Hematologic manifestations of brucellosis in children. Pediatr Infect Dis J 2018;37:586-91. [CrossRef]

6. El-Koumi MA, Afify M, Al-Zahrani SH. A prospective study of brucellosis in children: relative frequency of pancytopenia. Iran J Pediatr 2014;24:155-60. [CrossRef]

7. Okur M, Erbey F, Kaya A, Doğan M, Acar MN, et al. Retrospective clinical and laboratory evaluation of children with brucellosis. Pediatr Int 2012;54:215-8. [CrossRef]

8. Gotuzzo E, Carrillo C. Brucella. In: Gorbach SL, Barlett JG, Blacklow NR (eds). Infectious Diseases. $3^{\text {rd }}$ ed. Philadelphia: Lippincott, Williams \& Wilkins, 2004:1717-24. [CrossRef]

9. Brugnara C, Oski FA, Nathan DG. Diagnostic approach to the anemic patient. In: Orkin S, Nathan D, Fisher D, Ginsburg D Look TA, Lux S. (eds). Nathan and Oski's Hematology and Oncology of Infancy and Childhood. $8^{\text {th }}$ ed. Philadelphia: WB Saunders, 2015:293. [CrossRef]

10. Cembrowski GS, Chan J, Cheng C. NHANES 1999-2000 data used to create comprehensive health-associated race-, sex-and age-stratified pediatric reference intervals for the Coulter MAXM. Laboratory Hematol 2004; 10:245. [CrossRef]
11. Baker RD, Greer FR, Committee on Nutrition American Academy of Pediatrics. Diagnosis and prevention of iron deficiency and iron-deficiency anemia in infants and young children (0-3 years of age). Pediatrics 2010;126:1040-50. [CrossRef]

12. Orkin SH, Nathan DG, Ginsburg D, Look AT, Fisher DE, Lux SE (eds). Nathan and Oski's Hematology of Infancy and Childhood. $7^{\text {th }}$ ed. Philadelphia: WB Saunders Company, 2009:455-66. [CrossRef]

13. Uluğ M, Yaman Y, Yapici F, Can-Uluğ N. Clinical and laboratory features, complications and treatment outcome of brucellosis in childhood and review of the literature. Turk J Pediatr 2011;53:413-24. [CrossRef]

14. YumukZ, O'Callaghan D. Brucellosis in Turkey-- an overview. Int J Infect Dis 2012;16:228-35. [CrossRef]

15. Gül S, Satilmiş OK, Ozturk B, Gökçe MI, Kuscu F. Seroprevalence of brucellosis among children in the Middle Anatolia Region of Turkey. J Health Popul Nutr 2014;32:577-9. [CrossRef]

16. Tsolia M, Drakonaki S, Messaritaki A, Farmakakis Th, Kostaki M, Tsapra $H$, et al. Clinical features, complications and treatment outcome of childhood brucellosis in central Greece. J Infect 2002;44:257-62. [CrossRef]

17. Bosilkovski M, Krteva L, Caparoska S, Labacevski N, Petrovski M. Childhood brucellosis: review of 317 cases. Asian Pac J Trop Med 2015;8:102732. [CrossRef]

18. Sasan MS, Nateghi M, Bonyadi B, Aelami MH. Clinical features and long term prognosis of childhood brucellosis in northeast Iran. Iran J Pediatr 2012;22:319-25. [CrossRef]

19. Mantur BG, Akki AS, Mangalgi SS, Patil SV, Gobbur RH, Peerapur BV. Childhood brucellosis--a microbiological, epidemiological and clinical study. J Trop Pediatr 2004;50:153-7. [CrossRef]

20. Karaman K, Akbayram S, Bayhan Gl, Doğan M, Parlak M, Akbayram HT, et al. Hematologic findings in children with brucellosis: experiences of 622 patients in Eastern Turkey. J Pediatr Hematol Oncol 2016;38:463-6. [CrossRef]

21. Al-Eissa Y, Al-Nasser M. Haematological manifestations of childhood brucellosis. Infection 1993;21:23-6. [CrossRef]

22. Aypak A, Aypak C, Bayram Y. Hematological findings in children with brucellosis. Pediatr Int 2015;57:1108-11. [CrossRef]

23. Citak EC, Citak FE, Tanyeri B, Arman D. Hematologic manifestations of brucellosis in children: 5 years experience of an anatolian center. J Pediatr Hematol Oncol 2010;32:137-40. [CrossRef]

24. Yoldas T, Tezer H, Ozkaya-Parlakay A, Sayli TR, et al. Clinical and laboratory findings of 97 pediatric brucellosis patients in central Turkey. $J$ Microbiol Immunol Infect 2014;112:1682-4. [CrossRef]

25. Fanni F, Shahbaznejad L, Pourakbari B, Mahmoudi S, Mamishi S. Clinical manifestations, laboratory findings, and therapeutic regimen in hospitalized children with brucellosis in an Iranian Referral Children Medical Centre. J Health Popul Nut 2013;31:218-22. [CrossRef]

26. Colmenero JD, Reguera JM, Martos F, Sanchez-De-Mora D, Delgado $M$, Causse $M$, et al. Complications associated with Brucella melitensis infection: a study of 530 cases. Medicine (Baltimore) 1996;75:195-211. [CrossRef]

27. Karakukcu M, Patiroglu T, Ozdemir MA, Gunes T, Gumus H, Karakukcu C. Pancytopenia, a rare hematologic manifestation of brucellosis in children. J Pediatr Hematol Oncol 2004;26:803-6. [CrossRef]

28. Parlak M, Akbayram S, Doğan M, Tuncer O, Bayram Y, Ceylan N, et al. Clinical manifestations and laboratory findings of 496 children with brucellosis in Van, Turkey. Pediatr Int 2015;57:586-9. [CrossRef]

29. Buzgan T, Karahocagil MK, Irmak H, Baran Al, Karsen H, Evirgen O, et al. Clinical manifestations and complications in 1028 cases of brucellosis: a retrospective evaluation and review of the literature. Int $J$ Infect Dis 2010;14:469-78. [CrossRef] 